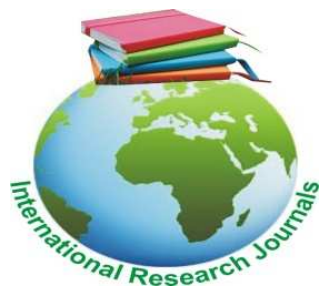

Educational Research (ISSN: 2141-5161) Vol. 8(2) pp. 021-026, April, 2017

Available online@ http://www.interesjournals.org/ER

DOI: http:/dx.doi.org/10.14303/er.2017.024

Copyright (C) 2017 International Research Journals

Full Length Research Paper

\title{
Reliability and content validity of the organized physical activity questionnaire for adolescents
}

\author{
${ }^{1}$ Carolina M. C. Campos ${ }^{\star},{ }^{2}$ Dayanna da Silva Oliveira, ${ }^{3}$ Anderson Henry Pereira Feitoza, ${ }^{4}$ Maria \\ Teresa Cattuzzo \\ 1/2/3/4 University of Pernambuco, Brazil \\ *Corresponding Author's Email: carolccampos@hotmail.com
}

\begin{abstract}
Objective: The purpose of this study was to develop and to determine reproducibility and content validity of the Organized Physical Activity Questionnaire for adolescents (OPAQA). Methods: Initially literature was reviewed and OPAQA was developed; after that the initial version of the OPAQA was reviewed by the co-authors and by 5 experts in the Exercise Science filed with emphases on conceptual framework and methodological knowledge about construction of questionnaires. Subsequently, the 5 experts and 77 participants (aged 11-18 years; boys $=33$ ) were used to evaluate content validity and reproducibility of the OPAQA respectively. Participants were asked to complete the OPAQA twice with an in-between period of approximately 2 weeks. Content Validity Coefficient (CVC), Kappa index and Spearman correlations were used for the analyses. Results: CVC were 0.83 (for current practice) and 0.82 (for previous practice); Kappa analyses ranged $0.37-0.95(p=0.002)$ for current practice and 0.82 for previous practice; Spearman correlations for overall reproducibility of OPAQA were $0.68(p<0.001)$ for current practice, and $0.75(p<0.001)$ for previous practice. In conclusion the OPAQA is a fairly reliable and reasonably valid questionnaire and may be used in researches that aim to investigate organized of physical activities in adolescents.
\end{abstract}

Keywords: Validation Study; Motor activity, Teenagers.

\section{INTRODUCTION}

Organized physical activity (OPA) can be considered one of the most important environment for children and adolescents achieve the recommendation for 60 minutes of moderate to vigorous physical activity (Alves et al., 2005; Malina et al., 2009; Malina, 2009). These activities can be defined as those that involve regular classes, training, or competition, are formally structured, and are led by a coach, instructor, or teacher (Okely et al., 2001). Some examples include playing soccer or basketball, swimming or athletics clubs or any other team or individual and attending dance or martial arts in general.

Tracking OPA in adolescents can be considered an important approach for improving youth health. The National Survey of Children's Health (Walsh et al., 2011) reported that $60 \%$ of youth were engaged in at least one OPA. Over those, $70 \%$ dropped out organized activity's programs prior high school. The reasons for drop out vary depending on gender, age, and intensity of participation, but the common reasons include, OPA conflicts with other activities, too much of a time commitment, excessive pressure and specially socioeconomic status and lack of fun (Burden and Dixon, 2013; Butcher et al., 2002; Russell, 2014; White and McTeer, 2012). The high rates of OPA dropout are troubling, because it represents a lack of opportunity to enhance youth health, such as increasing levels of moderate to vigorous physical activity (MVPA)(Machado-Rodrigues et al., 2012) and increasing bone mineral composition (Tenforde and Fredericson, 2011), through OPA.

Thus, understanding the mechanisms that facilitate regular participation and decrease in OPA, such as tracking of activities through lifespan (current and previous OPA), should be considered an important approach to improving youth health, since OPA have been considered one of the most important environments for youth to accumulate health enhancing levels of MVPA (Alves et al., 2005; Malina et al., 2009; Malina, 2009).

A self-report measurement is often the most feasible 
022 Educ. Res.

methodology to collect information on OPA. Because it is cost-effective, very efficient and easy to administer on a large-scale many studies investigating OPA have been used questionnaires (Buckworth and Nigg, 2004; Côté et al., 2007; Fransen et al., 2012; Leite et al., 2009; Pate et al., 2000; Telama and Yang, 2006; Vilhjalmsson and Kristjansdottir, 2003; Young et al., 2008). Fransen et al., (2012) investigating 735 boys (aged 6-12years) used the Flemish Physical Activity Computerized Questionnaire (Philippaerts et al., 2006). This questionnaire allowed the participant to report their participation in only one sport during the year how many hour per practice. Further, Balaguer et al. (2012) used the adaptation of the Health Behavior of School Children to assess OPA in adolescents. Participants responded what activities outside of school they were engaged (i.e. soccer, basketball, volleyball, tennis, handball, athletics, martial arts, aerobics, swimming, ballet, etc.), their frequency (never practice sport, practice less than once a week, practice once a week, practice between 2-3 times a week, practice between 4-5 times a week, and practice between 6-7 times a week) and the duration (ranging from less than 5 minutes, between 5-10 minutes, between 15-20 minutes, between 25-30 minutes, between 35 and 45 minutes and more than 45 minutes). However, to our knowledge literature does not provide valid instruments that also report adolescent's previous (more than one year of practice) OPA participation.

A systematic review (Helmerhorst et al., 2012) aimed to provide an updated review of the existing and more recently developed physical activity questionnaires (including OPA) review that only 4 questionnaires addressed to youth provide some kind of OPA measures (Martinez-Gomez et al., 2010; Ridley et al., 2006; Treuth et al., 2005; Welk et al., 2007). However, over those, none report adolescents' prior activities (prior a year) and specifically the Organized Physical Activity Questionnaire for adolescents (OPAQA) was designed to address this limitation. Thus, the objective of this study was to design an instrument that could be used to track OPA in adolescents and determine its reproducibility and content validity.

\section{METHODS}

\section{Study design and sample}

The instrument development included a literature review, input from 5 committee members, experts on the Exercise Science and Physical Education field, with emphases on conceptual framework and methodological knowledge about construction of questionnaires (Alexandre and Colluci, 2011), and test-retest from adolescents (aged 11-18 years) as suggested by the literature (Cassepp-Borges et al., 2010). All adolescents were Brazilians, recruited from an urban school district in northwest of Recife, Brazil, and had similar social status characteristics.

\section{Description of the OPAQA}

The OPAQA is a self-administered questionnaire and was developed to identify and prove sufficient detail on OPA participation (excluding physical education) in adolescents (current and previous activities). In the first section of the OPAQA students are asked to report the all types of the organized activity (e.g. swimming, soccer, ballet) that they were currently engaged. For each activity mentioned, the adolescents were asked the number of days (i.e., times attended per week) they usually practice. Next, students were then asked to report how long (duration in hours or minutes) they had spent doing each activity and the total time (months) spent in each activity (maximum six months). Second section of the questionnaire correspond to the OPA that adolescents were engaged prior the last six months. Same questions about type of activity, frequency, and duration were asked. In addition adolescents were also asked to report in what age they started to do the practice (i.e. since I was 5 years old) (Appendices).

\section{Procedures}

Prior to data collection, study procedures were approved by the local Ethics Committee and written informed consent was collected from all participants. Initially, an extensive review of the literature was carried out, in order to find previous questionnaires involving OPA. After that the OPAQA was develop by the authors.

\section{Content validity}

The initial version of the OPAQA was reviewed by the coauthors and by the 5 experts committee for further suggestions. Once the instrument was considered finalized, the experts were invited to examine the content validity. This committee evaluated the content validity of OPAQA, using a Likert scale developed by the investigation team. Experts expressed their degree of agreement according to the 1) clarity of the language, 2) practical relevance and 3) theoretical relevance of instrument, on a scale of 1 to 5 , justifying their score (1: nothing relevant or unclear; 5 : very relevant or very clear) (Cassepp-Borges et al., 2010). Acceptable level of content validity was set as 0.70 or higher (CasseppBorges et al., 2010).

\section{Reliability}

After modifying instruments to improve clarity and 
Table 1. Content validity coefficient (CVC) of the Organized Physical Activity Questionnaire for adolescents

\begin{tabular}{|c|c|c|c|}
\hline \multicolumn{4}{|c|}{ Organized Physical Activity (OPA) } \\
\hline Current OPA & Clarity & $\begin{array}{l}\text { Theoretical } \\
\text { relevance }\end{array}$ & $\begin{array}{l}\text { Practical } \\
\text { relevance }\end{array}$ \\
\hline & CVC Mean & CVC Mean & CVC Mean \\
\hline $\begin{array}{l}\text { Item } 1 \text { (current engagement in } \\
\text { OPA) }\end{array}$ & 0.80 & 0.85 & 0.76 \\
\hline Item 2 (type of OPA practiced) & 0.95 & 0.95 & 0.90 \\
\hline Item 3 (frequency) & 1.00 & 1.00 & 0.96 \\
\hline Item 4 (duration) & 0.85 & 0.90 & 0.83 \\
\hline $\begin{array}{l}\text { Item } 5 \\
\text { currently) }\end{array}$ (total time spent & 0.75 & 0.85 & 0.70 \\
\hline $\begin{array}{l}\text { Item } 6 \text { (practice on vacations } \\
\text { breaks) }\end{array}$ & 0.85 & 0.90 & 0.83 \\
\hline TOTAL & 0.86 & 0.90 & 0.83 \\
\hline \multirow[t]{2}{*}{ Previous OPA } & Clarity & $\begin{array}{l}\text { Theoretical } \\
\text { relevance }\end{array}$ & $\begin{array}{l}\text { Practical } \\
\text { relevance }\end{array}$ \\
\hline & CVC Mean & CVC Mean & CVC Mean \\
\hline $\begin{array}{l}\text { Item } 1 \text { (previous engagement in } \\
\text { OPA) }\end{array}$ & 0.75 & 0.85 & 0.90 \\
\hline $\begin{array}{l}\text { Item } 2 \text { (previous engagement in } \\
\text { OPA 2) }\end{array}$ & 0.75 & 0.75 & 0.70 \\
\hline Item 3 (type of OPA practiced) & 1.00 & 1.00 & 0.96 \\
\hline Item 4 (frequency) & 1.00 & 1.00 & 0.90 \\
\hline Item 5 (duration) & 0.90 & 0.95 & 0.83 \\
\hline $\begin{array}{l}\text { Item } 6 \\
\text { currently) }\end{array}$ (total time spent & 0.85 & 0.95 & 0.76 \\
\hline $\begin{array}{l}\text { Item } 7 \text { (practice on vacations } \\
\text { breaks) }\end{array}$ & 0.90 & 0.80 & 0.70 \\
\hline TOTAL & 0.87 & 0.90 & 0.82 \\
\hline
\end{tabular}

Note: $\mathrm{CVC}=$ Content validity coefficient

minimize response error, the OPAQA was applied, by trained researches, to the target population to determine its reliability. The reliability study was conducted at the facilities of the school in a regular Physical Education class time. Adolescents were asked to complete the OPAQA twice (Test-retest validity) with an in-between period of approximately 2 weeks. This period was determined based on the existing literature and on protocols used in similar studies in order minimize possible memory bias of the participants.

\section{Statistical analysis}

Initially, descriptive (median and Interquartile range) and normality (Kolmogorov-Smirnov) analysis were completed. Content Validity Coefficient (CVC) (Hernandez-Nieto, 2001) was used to assess the content validity. Kappa coefficient and Spearman correlations were used to examine reproducibility. Analyses were assessed by gender. The strength of correlations was defined as: low $=0.20-0.39$; moderate $=0.40-0.59$; moderately high $=0.60-0.79$ and high $\geq .80$ (Zhu, 2012). Data was analyzed with the SPSS (v. 20.0).

\section{RESULTS}

\section{Content validity}

Table 1 shows CVC results. Analyses reported that means for both, current and previous practice, CVC were higher than the acceptable level set $(\geq 0.70)$ for all items assessed (clarity of the language; practical and theoretical relevance).

\section{Reproducibility}

The Questionnaire was applied in 77 adolescents (girls 
024 Educ. Res.

Table 2: Spearman correlations of the Organized Physical Activity Questionnaire for adolescents by gender

\begin{tabular}{lcccccc}
\hline & \multicolumn{2}{c}{ Organized Physical Activity (OPA) } & & \\
\hline Current OPA & \multicolumn{2}{c}{ Boys $(\mathbf{n}=\mathbf{3 3})$} & Girls $(\mathbf{n}=\mathbf{4 4})$ & \multicolumn{2}{c}{ All $(\mathbf{n}=\mathbf{7 7})$} \\
\hline & rho & $\boldsymbol{p}$ & rho & $\boldsymbol{p}$ & rho & $\boldsymbol{p}$ \\
Frequency & 0.951 & 0.000 & 0.603 & 0.006 & 0.840 & 0.000 \\
Duration & 0.690 & 0.001 & 0.873 & 0.000 & 0.895 & 0.000 \\
Total time Spent & 0.810 & 0.000 & 0.481 & 0.027 & 0.684 & 0.000 \\
\hline & & & & & & \\
Previous OPA & rho & $\boldsymbol{p}$ & rho & $\boldsymbol{p}$ & rho & $\boldsymbol{p}$ \\
\hline & & & & & & \\
Frequency & 0.838 & 0.000 & 0.499 & 0.001 & 0.826 & 0.000 \\
Duration & 0.735 & 0.000 & 0.461 & 0.002 & 0.772 & 0.000 \\
Starting age of OPA & 0.509 & 0.018 & 0.532 & 0.006 & 0.656 & 0.000 \\
Total time spent & 0.710 & 0.000 & 0.456 & 0.002 & 0.752 & 0.000 \\
\hline
\end{tabular}

Note: OPA = Organized Physical Activity

Table 3. Kappa coefficients of the Organized Physical Activity Questionnaire for adolescents

\begin{tabular}{lccccccc}
\hline \multicolumn{3}{c}{ Organized Physical Activity (OPA) } \\
\hline Current OPA & \multicolumn{2}{c}{ Boys $(\mathbf{n}=\mathbf{3 3})$} & \multicolumn{2}{c}{ Girls $(\mathbf{n}=\mathbf{4 4})$} & \multicolumn{2}{c}{ All $(\mathbf{n}=\mathbf{7 7})$} \\
& Kappa & $\boldsymbol{p}$ & Kappa & $\boldsymbol{p}$ & Kappa & $\boldsymbol{p}$ \\
\hline Current engagement in OPA & 0.651 & 0.000 & 0.953 & 0.000 & 0.764 & 0.000 \\
Engagement during schools breaks & 0.719 & 0.000 & 0.919 & 0.000 & 0.772 & 0.000 \\
\hline Previous OPA & Kappa & $\boldsymbol{p}$ & Kappa & $\boldsymbol{p}$ & Kappa & $\boldsymbol{p}$ \\
\hline Previous engagement in OPA & 0.370 & 0.020 & 0.754 & 0.000 & 0.644 & 0.000 \\
Engagement during schools breaks & 0.750 & 0.000 & 0.713 & 0.001 & 0.742 & 0.000 \\
\hline
\end{tabular}

Note: OPA = Organized Physical Activity

$=44$; mean age $=14.0 \pm 2.6$ years; boys $=33$, mean age $14.1 \pm 2.4$ years). There were no differences between male and female participants' age. Overall, Spearman analyses reported moderate to high correlations for both current (rho $=0.68-0.89$ ) and previous practice (rho $=0.65-0.82$ ). Analyses by gender identified moderate to high correlations for boys $(r h o=0.69-0.95)$ and moderate correlations for girls de $(r h o=0.48-0.60)$ in current OPA and moderate to high correlations for boys (rho $=0.50-0.83$ ) and moderate correlations for girls de $(r h o=0.45-0.53)$ for engagement in previous OPA (Table 2).

Kappa coefficients are reported in table 3 . Results were considered moderate for current OPA $(k=0.76-$ $0.77)$ and moderate to high $(k=0.64-0.74)$ for previous OPA. Analyses by gender reported moderate coefficients for boys $(k=0.65-0.71)$ and high coefficients for girls $(k=$ 0.91-0.95) for current OPA and low to moderate coefficients for boys $(k=0.37-0.75)$ and moderate coefficients for girls $(k=0.64-0.74)$.

\section{DISCUSSION}

The purpose of this study was to develop and to determine reproducibility and content validity of the OPAQA and the results of this study demonstrate that estimates of OPA from the OPAQA in adolescents are reliable and valid. Mean of content validity coefficients from the 5 experts committee were considered high (CVC $>0.80$ ) for all items in both current and previous OPA and this results is consistent with the literature that reported high levels of clarity and pertinence of its instrument (Martinez-Gomez et al., 2010; Booth et al., 2002).

Regarding the reproducibility of the OPAQA, results also reported moderate to high Spearman's and Kappa's 
correlations assessing current $(k=0.76-0.77 / r h o=0.68$ $-0.89)$ and previous $(k=0.64-0.74 / r h o=0.65-0.82)$ OPS in adolescents. The higher reliability for estimates OPA is consistent with findings in previous studies in youth aimed to determine reproducibility using test-retest protocols (Martínez-Gómez et al., 2010). Typically, values of $\geq 0.70$ for Spearman's and Kappa's correlations are considered to be the criterion for acceptable testretest reliability; however, the present study reported higher values when compared with previous studies (Helmerhorst et al., 2012; Militão et al., 2013; Janz et al., 2005; Wong et al., 2006). Taken together these results provide support for the reliability and validity of the OPAQA used as OPA assessment.

When stratified by gender, reproducibility of the OPAQA reported gender differences of the coefficients' magnitudes, with boys being, in general, more consistent with their answered when compared with girls for current (boys $k=0.65-0.71 /$ rho $=0.69-0.95$; girls $k=0.91-$ $0.95 /$ rho $=0.48-0.60)$ and previous (boys $=(k=0.37-$ 0.75 / rho $=0.50-0.83$; girls $k=0.64-0.74 /$ rho $=0.45-$ $0.53)$. These results are consistent with the literature that has reported that boys and girls answer questionnaires related with physical activity differently (Nahas et al., 2007; Martínez-Gómez et al., 2010). Literature has suggested that differences of answers consistency might be related with the level of physical activity of the participants (Farias Júnior et al., 2012). According with Kamtsios et al., (2010), boys in general are more involved in OPA when compared with girls and this can contribute for the higher retention of information about the details of the practice, when compared with girls (Farias Júnior et al., 2012). Thus, is not surprising that in this study, reproducibility of the OPAQA among boys were higher.

\section{Perspectives}

Organized Physical Activity has the potential to achieve fundamental goal in youth development, such as improving physical health and learning motor skills. Although important, analysis of short periods of OPA can include the effects of seasonal variations and random life events that may not reflect the participation in OPA during longer periods of time. Thus, tracking adolescent's OPA can represent potentially strong information about a habit that is related to positive building experiences. The results of the present study showed that OPAQA had an adequate reliability and content validity for assessing OPA in adolescents and it presents advantages over others instruments. In the OPAQA students were asked to provide detailed information (i.e. type, frequency, duration, age of engagement and time spent) about current and previous OPA performed and this information is considered a public health interest. Professional and researches can use it in order to evaluate participation in
OPA (current and previous), identifying and understanding their lifetime exposures, which might facilitate regular participation and decrease dropout in OPA. However, although the OPAQA was considered fairly valid for adolescents, some evidence from our result suggests that reliability were better among boys and additional research is needed, in order to more systematically evaluate gender differences.

\section{ACKNOWLEDGEMENT}

This work was supported by the state Funding Agency FACEPE under Grant IBPG-0721-4.09/12 and by the Coordenação de Aperfeiçoamento de Pessoal de Nível Superior (CAPES) under Grant BEX 2568/13.

\section{REFERENCES}

Alexandre N, Coluci (2011). Validade de conteúdo nos processos de construção e adaptação de instrumentos de medidas. [Content validity in the development and adaptation processes of measurement instruments]. Ciência and Saúde Coletiva: 16.7: 3061-3068. Retrieved from http://dx.doi.org/10.1590/S141381232011000800006

Alves M, Oliveira, Alves (2005). Prática de esportes durante a adolescência e atividade física de lazer na vida adulta. Rev. Bras. Med Esporte: 11(5), 291-294. Retrieved from http://dx.doi.org/10.1590/S1517-86922005000500009

Balaguer I, Atienza FL, Duda JL (2012). Self-perceptions, self-worth and Sport participation in adolescents. The Spanish Journal of

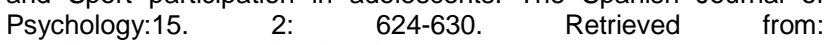
http://www.redalyc.org/pdf/172/17223158018.pdf

Booth M, Okely A, Chey T, Bauman A (2002). The reliability and validity of the Adolescent Physical Activity Recall Questionnaire. Med Sci Sports Exerc: 34(12): 1986-1995. Retrieved from DOI:10.1249/01.MSS.0000038981.35052.D3

Buckworth, J, Nigg C (2004). Physical activity, exercise, and sedentary behavior in college students. J. American College Health: 53.1: 2834 Retrieved from www.tandfonline.com/doi/abs/10.3200 JJACH7.53.1.28-34

Burden T, Dixon M (2013). Adolescent Withdrawal from Sport Participation: An Integrated Approach. Journal for the Study of Sports and Athletes: 7.3: 149-167 Retrieved from www.tandfonline.com/doi/abs/10.1179/1935739713Z.00000000010

Butcher J, Lindner K, Johns D (2002). Withdrawal from competitive youth sport: A retrospective ten-year study. J. Sport Behavior 25.2: 145-163 Retrieved from search.proquest.com/openview/461b3f30ea 741b7b78954d5ad587538a/1?pq-origsite=gscholar

Cassepp-Borges V, Balbinotti M, Teodoro M (2010). Tradução e validação de conteúdo: uma proposta para a adaptação de instrumentos: 506-520. In. Pasquali, L. (Org). Instrumentação psicológica. Fundamentos e Práticas. Porto Alegre: Artmed.

Côté, J, Baker J, Abernethy B (2007). Practice and play in the development of sport expertise. Handbook of Sport Psychology Retrieved from books.google.com.br/books?hl=enandlr=andid=h2m 7196ZStgCandoi=fndandpg=PA184anddq=Practice + and + Play+in+th e+Development+of+Sport+Expertise $+\ldots$ andots $=5 c x E S j o U H 0$ andsig =3g1IQ9vkCT8CfBWuVJN2mv0nTZM

Farias Júnior J, Lopes A, Mota J, Santos M, Ribeiro J, Hallal P (2012). Validade e reprodutibilidade de um questionário para medida de atividade física em adolescentes: uma adaptação do SelfAdministered Physical Activity Checklist. Rev Bras Epidemiol,: 15.1: 198-210. Retrieved from http://dx.doi.org/10.1590/S1415-790 X201 2000100018

Fransen J, Pion J, Vandendriessche J, Vandorpe B, Vaeyens R, Lenoir 
026 Educ. Res.

M, and Philippaerts RM (2012). Differences in physical fitness and gross motor coordination in boys aged $6-12$ years specializing in one versus sampling more than one sport. J Sports Sci. : 30.4: 379386. Retrieved from www.researchgate.net/profile/ JobFransen 2/publication/51980777 Differences in physical fitness and gross motor coordination in boys aged 612 years specializing in on e versus sampling more than one sport/links/56c6465b08ae03b 93dda52d2.pdf

Helmerhorst HJ, Brage S, Warren, J, Besson H, Ekelund U (2012). A systematic review of reliability and objective criterion-related validity of physical activity questionnaires. Intl. J. Behavioral Nutrition and Physical Activity: 9.103. Retrieved from www.academia.edu /download/39532763/A systematic review of reliability and 0201 51029-9890-16us1um.pdf

Hernández-Nieto M (2001).. Contribuiciones al análisis estadístico: sensibilidad (estabilidad y consistencia) de varios coeficientes de varibilidad relativa y el coeficiente de variacion proporcional (CVP). El coeficiente de validez de conetenido (CV) y el coeficiente Kappa, en la determinación de la valizes de contenido según la técnica de juicio de exteros. Unisersidad de Los Andes.

Janz K, Broffitt B, Levy S (2005). Validation evidence for the Netherlands physical activity questionnaire for young children: the lowa Bone Development study. Res Q Exerc Sport.: 76.3: 363-392. DOI:10.1080/02701367.2005.10599308

Kamtsios S (2010). Gender differences in elementary school children in perceived athletic competence, body attractiveness, attitudes towards exercise. Int. q. sport sci: 76.3: 363-369. Retrieved from mstt.hu/igss/issues/20102/2 Kamtsios IQSS 2010 2.pdf

Leite, N, Baker J, Sampaio, J (2009). Paths to expertise in Portuguese national team athletes. J Sports Sci Med:: 8.4: 560-566. Retrieved from www.researchgate.net/profile/Jaime Sampaio/ publication/ 258035500 Paths to expertise in Portuguese national team athl etes/links/0912f50bcb60b713f2000000.pdf

Machado-Rodrigues A, Coelho S, Mota J, Santos RM (2012). Coming $S$, and Malina R. Physical activity and energy expenditure in adolescent male sport participants and nonparticipants aged 13 to 16 years. J Phys Act Health. 9.5: 626-633. Retrieved from journals.humankinetics.com/AcuCustom/Sitename/Documents/Docu mentltem/03 machado-rodrigues JPAH 20100283 626-633.pdf

Malina R (2009). Children and Adolescents in the Sport Culture: The Overwhelming Majority to the Select Few. Journal of Exercise Science and Fitness: 7.2, S1-S10. Retrieved from citeseerx.ist.psu.edu/viewdoc/download?doi=10.1.1.584.3544andre $\mathrm{p}=$ rep1andtype $=\mathrm{pdf}$

Malina R, Bouchard C, Bar-Or O (2009). Crescimento, maturação e Atividade Física ( $2^{\mathrm{a}}$ ed.). São Paulo: Ed. Phorte..

Martínez-Gómez D, Calabro MA, Welk GJ, Marcos A, Veiga OL (2010). Reliability and validity of a school recess physical activity recall in Spanish youth. Pediatr Exerc Sci: 22:218-230. Retrieved from www.researchgte.net/profile/OscarVeiga/publication/44691503Relia bilityand validity of a school recess physical activity recall in S panish youth/links/0ł3175345c32ccde55000000.pdf

Militão A, Silva F, Peçanha L, Souza J, Militão E, Campbell C (2013). Reprodutibilidade e validade de um questionário de avaliação do nível de atividade física e comportamento sedentário de escolares de 10 a 13 anos de idade, Distrito Federal, Brasil. Epidemiol. Serv. Saúde. 22.1: 111-120. Retrieved from www.def.unir.br/downloads /2502 trabalho a.pdf

Nahas M, Barros M, Florindo A, Farias Junior J, Hallal P, Konrad L, Konrad L, Barros S, Assis M (2007). Reprodutibilidade e validade do questionário saúde na boa para avaliar atividade física e hábitos alimentares em escolares do ensino médio. Rev. bras. ativ. fís. Saúde.: 12.3: 12-20. Retrieved fromwww.researchgate. net/profile/markus nahas/publication/237268691 reprodutibilidade e validade do questionrio sade na boa para avaliar atividade $f$ sica e hbitos alimentares em escolares do ensino mdio/links/00 46351bf6cb650fee000000.pdf

Okely A, Booth M, Patterson J (2001). Relationship of physical activity to fundamental movement skills among adolescents. Med SCi Sports Exerc.: 33.11: 1899-1904. Retrieved from dx.doi.org/10.1097/00005768-200111000-00015

Pate R, Trost S, Levin S, Dowda M (2000). Sports participation and health-related behaviors among US youth. Archives of pediatrics and adolescent medicine. 154.9: 904-911. Retrieved from www.researchgate. net/profile/Sarah Martin13/publication/12341070 Sports Participation and $\mathrm{H}$ ealthRelated Behaviors Among US Youth/links/57435e3a08aea45ee84d0f6 a.pdf

Philippaerts, RM, Matton L, Wijndaele K, Balduck AL, De Bourdeaudhuij I, Lefevre J (2006). Validity of a physical activity computer questionnaire in 12- to 18-year-old boys and girls. Intel. J. of Sports Med.: 27, 131-136. Retrieved from www.academia.edu/download/ 40409000/Validity of a physical activity computer2015112628668-uuqhda.pdf

Ridley K, Olds TS, Hill A (2006). The Multimedia Activity Recall for Children and Adolescents (MARCA): development and evaluation. Behav Nutr Phys Act.: 3:10. Retrieved from europepmc.org/ articles /7PMC1524806

Russell W (2014). The relationship between youth sport specialization, reasons for participation, and youth sport participation motivations: A retrospective study. J. Sport Behavior: 37.3: 286-305 Retrieved fromsearch.proquest.com/openview/347ff2e8717f4facf06af5d85a7e $67 \mathrm{ae} / 1$ ?pq-origsite $=$ gscholar

Telama R, Yang X (2016). Participation in organized youth sport as a predictor of adult physical activity: a 21-year longitudinal study. Pediatric Exercise: 17: 76-88 Retrieved from journalsHumankinetics .com/AcuCustom/Sitename/Documents/Documentltem/5426.pdf

Tenforde A, Fredericson M (2011). Influence of sports participation on bone health in the young athlete: a review of the literature. $P M$ and R: 3.9: 861-867 Retrieved from www.pmrjournal.org/article/S1934$1482(11) 00390-X / p d f$

Treuth MS, Sherwood NE, Butte NF, McClanahan B, Obarzanek E, Zhou A, Ayers C, Adolph A, Jordan J, Jacobs DR, and Rochon J (2003). Validity and reliability of activity measures in AfricanAmerican girls for GEMS. Med Sci Sports Exerc: 35.3: 532-539 Retrieved from www.researchgate.net/profile/Nancy Sherwood/ publication/10871521 Validity and reliability of activity measures in AfricanAmerican girls for GEMS/links/542ac6b20cf277d58e89 7295.pdf

Vilhjalmsson R, Kristjansdottir G (2003). Gender differences in physical activity in older children and adolescents: the central role of organized sport. Social Science and Medicine: 56.2: 363-374. Retrieved from doi.org/10.1016/S0277-9536(02)00042-4

Walsh J, Tannehill D, Woods C (2011). The Children's Sport Participation and Physical Activity Study (CSPPA)-Volunteer Study. Dublin: Dublin City University, Retrieved from scholar.google.com.br/scholar?q=The+Children\%E2\% $80 \% 99$ s+Sport+Particip ation+and +Physical+Activity +Study+\%28CSPPA\%29.+andbtnG=andhl=enan das $\mathrm{sdt}=0 \% 2 \mathrm{C} 41 \# 1 \# 0$

Welk GJ, Wickel E, Peterson M, Heitzler CD, Fulton JE, Potter LD (2007). Reliability and validity of questions on the youth media campaign longitudinal survey. Med Sci 1Sports Exerc: 39.4: 612621.Retrieved from www.researchgate.net/publication/6407029 Reliability and Validity of Questions on the Youth Media Campaign Lon gitudinal Survey?el=1 x 8andenrichld=rgreq2fede4666b1db2347b7c904298 abdfcaandenrichSource $=$ Y292ZXJ QYWdlOzU1MzU1NzU7QVMGMTUyMjM2 MiU2NiY1NiAwQDEOMTMZMDczNiA4Mzk

White P, McTeer W (2012). Socioeconomic status and sport participation at different developmental stages during childhood and youth: Multivariate analyses using Canadian. Sociology of Sport J.: 29: 186-209. Retrieved from journals.humankinetics.com/Acu Custom/Sitename/Documents/Documentltem/04 mcteer SSJ 110 130 186-209.pdf

Wong S, Leatherdale S, Manske S (2006). Reliability and validity of a school-based physical activity questionnaire. Med Sci Sports Exerc. 38.9: 1593-1600. Retrieved from dx.doi.org/10.1249/01.mss .0000227539 .58916 .35

Young BW, Medic N, Weir PL, Starkes JL (2008). Explaining performance in elite middle-aged runners: contributions from age and from ongoing and past training factors. J. Sport and Exerc. Psychology: 30.6, 737-754. Retrieved from www.ncbi.nlm.nih.gov/ pubmed/19164839

Zhu W (2012). Sadly, the earth is still round $(p<0.05)$. J. Sport Heal. Sci.: 1.1:9.11. Retrieved from: http://linkinghub.elsevier.com /retrieve/pii/S209525461200006 